
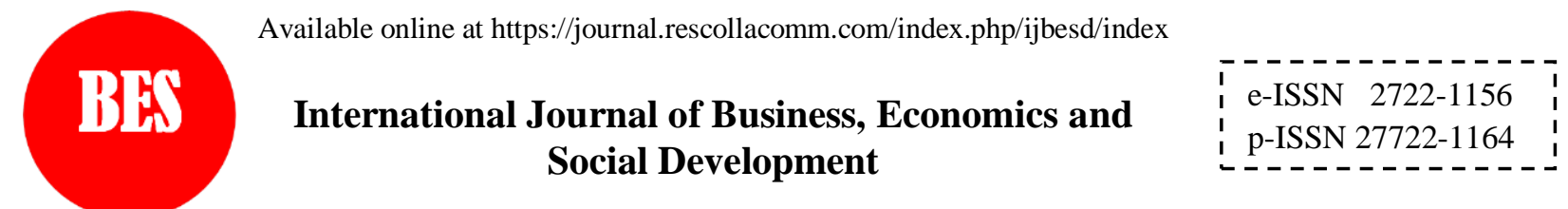

Vol. 1, No. 3, pp. 105-111, 2020

\title{
Marine Tourism Benefit from Economic Perspective (Case in Pari Island, Indonesia)
}

\author{
Agnes Puspitasari Sudarmo \\ Department of FisheryManagement Graduate Program, Faculty of Scinece and Technology, Universitas Terbuka, Tangerang Selatan, Banten \\ 15418, Indonesia
}

Corresponding authore-mail address:agnes@ecampus.ut.ac.id

\begin{abstract}
tourism as new emerging economic icon had potential economic growth to promote Indonesia's economic development. One of the islands that attract many visitors who want to enjoy marine tourism is Pari Island, which lies in Kepulauan Seribu, Jakarta. The study was conducted in June 2017 until October 2017 on Pari Island, Kepulauan Seribu, Jakarta. The research method used is descriptive. Sample was tourist from domestic as well as foreign countries who travelled to Pari Island. Data collection was gathered by survey techniques, which are complemented by observation, and interviews. For data collection using survey techniques, only respondents who were willing were given a questionnaire to fill out the questionnaire. Data was analyzed using descriptive and PCA.
\end{abstract}

Keywords: Marine tourism, qualitative descriptive, economic development, Principal Component Analysis.

\section{Introduction}

Marine tourism as new emerging economic icon and had potential economic growth resources to promote Indonesia's economic development (Kurniawan et al., 2016a, 2016b; Nobi \& Majumder, 2019; Towner, 2016; Ziegler et al., 2019). For Indonesia, advancing maritime tourism is something that needs to be supported considering that Indonesia is a very strategic and large archipelago. Marine tourism as well as coastal tourism is one of the sources of new economic growth with potential and economic value that is promising but its utilization is not optimal. This condition occurred in Bangladesh as stated by Nobi \& Majumder (2019) that the utilization of vast and large coastal areas in Bangladesh if managed properly can increase economic development through marine tourism. In addition, it should be noted that the development of coastal area or the management of small islands into marine tourism destination needs to pay attention to their designation as well as biodiversity so that the sustainability aspect is maintained (Kurniawan et al., 2016a; Ziegler et al., 2019)

The sector of economic growth currently being promoted in Indonesia is related to marine tourism. The country of Indonesia is a maritime country so that it is appropriate to make the maritime sector as the prime economic movers or the main drivers of the economy in Indonesia (Basri \& Rahardja, 2010). Many spot tourists have been initiated to explore the natural beauty and scenic of Indonesia, especially spots that have potential coastal and marine attraction. 
The regions in Indonesia that has promising natural and marine resource potential is the Kepulauan Seribu Administration District or better known as the Thousand Islands. In the Kepulauan Seribu there are many islands that each of these islands has a uniqueness natural beauty. One of the islands that are attracted by people who want to enjoy marine tourism is Pari Island which is in the Kepulauan Seribu (Thousand Islands cluster) in the waters of the North Coast of the Java Sea to the north of the Bay of Jakarta. The Pari island has evolved as a marine tourism destination, many tourists have visited it to enjoy and feel the natural atmosphere in this island.

The location is very strategic because of the distance is not far from the center of the capital city of Jakarta so that it is easily accessible. The island can be reached by boat which can be assessed form Marina or Muara Angke harbor. Since the distance of the island close to the capital city, this allows many people to visit Pari Island. Pari Island also has the natural beauty of the beach and sea which has a variety of aquatic biota such as coral reefs, mangroves, ornamental fish and others. For nature tourist, the beauty of underwater scenery as well as natural atmosphere in the island have become a magnet for people to explore it. In the long run, tourists who travelled to Pari Island must be given adequate information and knowledge about the right environmentally friendly travel procedure to preserve and maintain the nature of the island.

However, on the other hand, tourists visiting Pari Island also have a negative impact, because not all tourists have the same understanding of actions to preserve marine tourism to be sustainable. In other words, sustainability related to good marine tourism needs to be maintained. This can be related to nonenvironmentally friendly actions that should not be carried out by visitors, such as thrown garbage, pulling out mangroves, or taking marine biota that must be avoided by tourists.

If the non-environmentally actions continued, such as pulled out mangroves, took marine biota and shellfish for commercial purposes and others, it will be caused that the amount of garbage scattered made the scenery looked dirty. If undesirable actions are allowed continuously for a long time, it will affect the mangroves, shellfish, and other marine biota on the island, which will adversely affect the health of the marine ecosystem. In the end, this will also have an impact the sustainability of marine tourism in Pari Island.

Other problems faced related to the sustainability of marine tourism in Pari Island are reduction island area due to abrasion, suctioning of sand for reclamation, bleaching corals, dredged corals, depletion of mangrove forests in the coastal areas of Pari Island (LIPI, 2015). Besides that, the beauty of white sand on Pari Island is threatened because of a reclamation project that takes sand from the sea which causes damage to coral reefs and this threaten the sustainability of marine tourism on the island (LIPI, 2015). Another problem that quite disturbing is the amount of plastic waste that is carried away by the ocean current and drifting on the shore of Pari island. The plastic garbage polluting the beaches around the Pari Island, and the existence of plastic waste is very disturbing for both residents and visitors.

With all the facts explained earlier, this article aims to explain the benefits of marine tourism in an economic perspective in relation to the sustainability of marine tourism by taking an example on Pari Island in the Kepulauan Seribu, Jakarta.

\section{Materials and Methods}

\subsection{Time and Location of Research}

The study was conducted in June 2017 until October 2017 on Pari Island, Kepulauan Seribu, Jakarta. The research method used is descriptive. Sample was tourist from domestic as well as foreign countries who travel to Pari Island. Data collection employed survey techniques, which are complemented by observation, and interviews. For data collection using survey techniques, only respondents who were willing to participate were given a questionnaire to fill out the questionnaire.

\subsection{Data Types and Data Collection Methods}

This type of data consists of primary data and secondary data. The primary data obtained from the survey results are expanded by observation of in-depth interviews to respondent. Respondents in this 
case tourists who travel to Pari island from domestic as well as foreign countries. Secondary data was obtained by literature study, Tourism office of Kepulauan Seribu, Bureau Statistics office of Kepulauan Seribu, Marine Fisheries office of Kepulauan Seribu.

\subsection{Data Analysis Method}

Data analysis was performed using descriptive analysis and Principal Component Analysis (PCA). All calculations in this study are performed using of IBM SPPS Statitics 22 software.

\section{Results and Discussion}

\subsection{General Condition of Pari Island}

The research location is in Pari Island, Kepulauan Seribu, Jakarta (South Seribu Islands District) see Figure 1. Pari island is one of the villages in the South Seribu Islands sub-district, which has an area $0.95 \mathrm{~km}^{2}$ (BPS Kabupaten Administrasi Kepulauan Seribu, 2020). Research location is selected intentionally. The reason for choosing this location is because Pari Island is one of the developing islands as a marine tourism destination and has enchanting waters so that more and more tourists visit the island. Pari Island lies in the waters of the North Coast of the Java Sea to the north of the Jakarta Bay (Figure 1). The time of the research was carried out between June 2017 and October 2017.

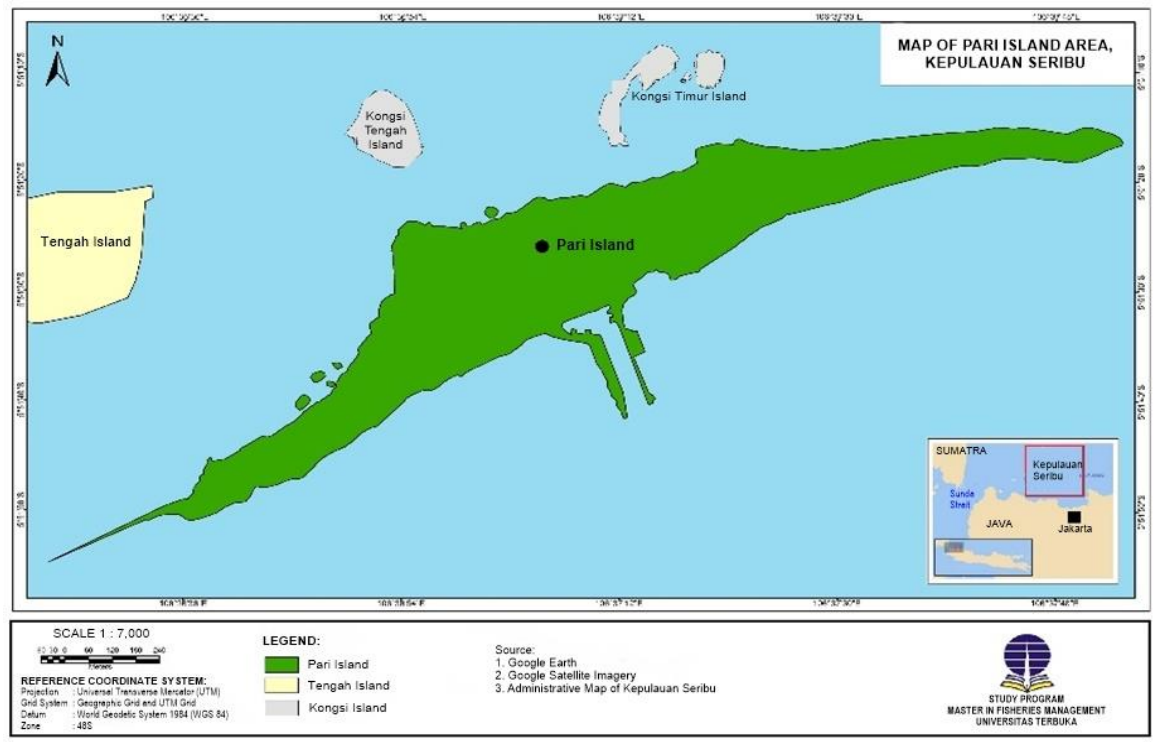

Figure 1: Pari Island, Kepulauan Seribu, Jakarta.

\subsection{General Profile of Respondents}

The general profile of the research respondents can be described as follows: There are 113 men $(61.7 \%)$ and 70 people are women $(38.3 \%)$. The age of respondents of tourists visiting Pari island in the age range 20-29 were 124 tourists $(67.75 \%)$. From the age range of tourists visiting Pari Island, it can be stated that this age of 20-29 signified that most visitors are young. Referring to the age category according to the Ministry of Health (2009), this age range is in the category of late adolescents (17-25) years and early adults (26-35) years. The age range of 20-29 is productive people; they have high enthusiasm and adventure. Where (Hurlock, 1991) stated the characteristics of early adulthood is the existence of changes related to appearance such as bodily functions, interests and attitudes and social behavior. If this is related to the age and characteristics of the early adulthood, it can be understood that respondents are young people who have a high interest in new things. 


\subsection{Economic Conditions}

The aspect of sustainability in terms of economics can be seen that overall the tendency of tourist responses is to agree and strongly agree that is a range of 99 people (86.84\%) to 166 people (98.22\%) as shown in Table 1. Of the five statements related to sustainability from the economic aspect, all these statements show the tendency that respondents strongly agree and agree with the percentage of responses above $80 \%$.

A statement that shows the highest response is related to business opportunities. In reality, there were many people who try to trade or do small businesses things that are related to the tourism industry. Respondents stated that they agreed and strongly agreed as many as 166 people $(98.22 \%)$, the situation in Pari island provided business opportunities for the local population. The situation on the island allows the local population to develop a good business climate, where there is no business competition between them, they help each other support one another. For example, if their lodging is full, they will inform other lodging if the tourists are willing to stay in the island.

The statement to support economic independence by local population are responded by 158 people (96.93\%) who are agree and strongly agree. The form of small businesses such as diving equipment rental, diving suits, boat rental for snorkeling, restaurant business, laundry services, grocery store, souvenir shop, bicycle rental, boat rental to mangrove forest, water bicycle rental, guide tourism services, provider of fresh fish, doing lodging business. All these business activities arise because of the demand and needs related to tourist arrivals to the island.

Table 1: Response Traveller to Statement That Are Relating to Economic Aspects

\begin{tabular}{|c|c|c|c|c|c|c|}
\hline Economic Aspects & SD & D & A & $\mathrm{SA}$ & SD and D & $\mathrm{A}$ and $\mathrm{SA}$ \\
\hline $\begin{array}{l}\text { Positive influence } \\
\text { in economic terms }\end{array}$ & 4 & 1 & 80 & 72 & $5(3.19 \%)$ & $152(96.82 \%)$ \\
\hline Additional income & 3 & 2 & 77 & 79 & $5(3.11 \%)$ & $156(96.89 \%)$ \\
\hline $\begin{array}{l}\text { Empowering the } \\
\text { Small Micro } \\
\text { Enterprise (SME) } \\
\text { sector }\end{array}$ & 3 & 12 & 70 & 29 & $\begin{array}{c}15 \\
(13.16 \%)\end{array}$ & $99(86.84 \%)$ \\
\hline $\begin{array}{l}\text { Population } \\
\text { economic } \\
\text { Independence }\end{array}$ & 2 & 3 & 70 & 88 & $5(3.07 \%)$ & $158(96.93 \%)$ \\
\hline $\begin{array}{l}\text { Business } \\
\text { opportunities }\end{array}$ & 1 & 2 & 70 & 96 & $3(1.78 \%)$ & $166(98.22 \%)$ \\
\hline
\end{tabular}

Note:

$\mathrm{SD}=$ strongly disagree; $\quad \mathrm{SA}=$ strongly agree

$\mathrm{D}=$ disagree

$\mathrm{A}=$ agree

Of all the economic activities that took place on Pari Island, it turned out that the most important thing to underline is that the activities carried out by the residents turned out to provide additional income to the residents who worked on the business in the small micro business sector. This statement of additional income was responded to in agree and strongly agree by the respondents at $96,80 \%$. This also has a positive influence on the economic aspects, which responded to $96.82 \%$ of respondents.

Travelers stated agree and strongly agree that the community on Pari island has been empowered in the small and medium enterprise (SME) sector, as many as 99 people (86.84\%). Small businesses carried out by residents such as homestays, tourism services, restaurant businesses need to be improved to support the economic independence of the local population. 
The socio-economic condition of the community in general are fishermen and some are also in seaweed cultivation where the level of education is still low, health facilities are still lacking, the social network between islands are still low (Putranto, 2015). But it has a high level of kinship and cooperation between communities in Pari Island. In this research, it revealed that the livelihoods of residents (local people) in Pari island majority are as fishermen who catch fish for their daily needs.

On the other hand, the residents in Pari island have a side job that related to marine tourism.

At the time this research was carried out, there were slightly residents who still cultivated this seaweed. Previously, majority of local people cultivated seaweed cultivation. There is an increase in income, because of the abundant seaweed harvest. Seaweed cultivation had dominated livelihoods in the Kepulauan Seribu (Thousand Islands), especially Panggang Island, Pramuka Island, Pari Island and Kelapa Island until the mid-1990s. The processed seaweed is sold to tourists on the islands which are the main tourist destinations in Kepulauan Seribu, such as Pramuka island, Pari island, and Tidung island.

However, entering year 2000 began to feel a decline in yields, even now the condition of seaweed cultivation in the Kepulauan Seribu can be said to be almost dead. Cultivators feel that sea water conditions are now inadequate for seaweed growth. Since, there are problems with the decrease in seaweed production produced, one of which is caused by a decrease in sea water quality so that local residents do not intend to do seaweed cultivation anymore because they do not see the economic benefits of seaweed cultivation.

Respondents agreed and strongly agreed that tourist arrivals gave an additional 156 people (96.89\%). The existence of marine tourism gives a positive part in terms of economy for the population as issued by 152 respondents $(96.82 \%)$. As explained in the explanation, that the people in the islands are involved in various businesses that are needed by tourists and businesses related to industrial tourism.

Although the scale of the business is small, because every weekend, especially during public holidays or religious holidays there must be tourists visiting there, of course there is income earned by this microscale business. Looking at the conditions of the houses of residents, it is necessary to change the condition of people's homes to accommodate the needs of tourists for proper housing and accommodation.

The general condition of residential areas varies depending on the level of welfare of the population. In general, the condition of residents' houses is walled walls, ceramic tile floors, and enough ventilation. Most of the houses that are used as a place to stay are generally also equipped with air conditioning (AC). Electricity on the island is supplied by micro hydro power plants.

\subsection{PCA Analysis}

For reduce the variables that really are affect the economic sustainability, the Principal Component Analysis (PCA) method is used (Gaspar et al., 2007; Hansmann et al., 2012; Radovanović et al., 2018). The results of the calculation of the correlation between statements ( 5 items) indicated by the reliability analysis related to aspects of sustainability from an economic standpoint showed high correlation values. Table 2 showed the results of the reliability calculation with Spearman correlation showed a correlation value of 0.86 (Table 2). These showed that the items / statements are convincingly correlate and strengthen one another.

Table 2: Reliability statistics

\begin{tabular}{ccc}
\hline & $\begin{array}{c}\text { Cronbach's Alpha Based on } \\
\text { Standardized Items }\end{array}$ & N of Items \\
\hline, 863 &, 880 & 5 \\
\hline
\end{tabular}

Table 3 described Total Variance Explained Economic Factors that were analyzed using the PCA (Principal Component Analysis) on the economic factors. The output here is defined as component 1 and column variance $\%$ is 68.35 which means the factors (dimensions) used in factor analysis can explain the variation of $68.35 \%$. This number is quite large because it is proven to explain more than $50 \%$ of the variance of variables. 
Table 3: Total variance explained economic factor using PCA

\begin{tabular}{|c|c|c|c|c|c|c|}
\hline \multirow[b]{2}{*}{ Components } & \multicolumn{3}{|c|}{ Initial Eigenvalues } & \multicolumn{3}{|c|}{ Extraction Sums of Squared Loadings } \\
\hline & Total & $\begin{array}{c}\% \text { of } \\
\text { Variance }\end{array}$ & $\begin{array}{c}\text { Cumulative } \\
\%\end{array}$ & Total & $\begin{array}{c}\% \text { of } \\
\text { Variance }\end{array}$ & $\begin{array}{c}\text { Cumulative } \\
\%\end{array}$ \\
\hline $\begin{array}{l}\text { 1. Give a positive } \\
\text { impact on the } \\
\text { economic sector }\end{array}$ & 3.42 & 68.35 & 68.35 & 3.42 & 68.35 & 68.35 \\
\hline $\begin{array}{l}\text { 2. Provide } \\
\text { additional income }\end{array}$ & 0.71 & 14.15 & 82.50 & & & \\
\hline $\begin{array}{l}\text { 3. Empowering the } \\
\text { Small Micro } \\
\text { Enterprise (SME) } \\
\text { sector }\end{array}$ & 0.38 & 7.64 & 90.14 & & & \\
\hline $\begin{array}{l}\text { 4. Giving } \\
\text { economic } \\
\text { independence to } \\
\text { the population }\end{array}$ & 0.31 & 6.27 & 96.41 & & & \\
\hline $\begin{array}{l}\text { 5. Business } \\
\text { opportunities }\end{array}$ & 0.18 & 3.59 & 100.00 & & & \\
\hline
\end{tabular}

Extraction Method of Principal Component Analysis

\section{Conclussion}

The results of the study can be concluded that in general the economic benefits obtained from the existence of marine tourism are very positive because they can support the sustainability of marine tourism in Pari Island. The presence of tourists visiting there will also promote the economic potential of the people on Pari island. In addition, tourists who come also encourage small micro-businesses to develop and provide additional income for the local population.

To maintain the sustainability and good condition of the community and nature on this island, tourists who visit must be educated so that they respect the wisdom of local values in the community and the natural beauty of Pari island by keeping their attitudes and behavior as good as possible.

\section{Acknowledgments}

The author would like to thank the Universitas Terbuka Research and Community Service Institute for providing financial assistance in the 2017 fiscal year so that this research can be carried out.

\section{References}

Basri, M Chatib \& Rahardja, S. (2010). The Indonesian Economy amidst the Global Crisis: Good Policy and Good Luck. ASEAN Economic Bulletin, 27, 77-97. https://doi.org/https://www.researchgate.net/deref/http\%3A\%2F\%2Fdx.doi.org\%2F10.1353\%2Fase .2010 .0017

BPS Kabupaten Adminstrasi Kepulauam Seribu.. (2020). Kepulauan Seribu Selatan Dalam Angka 2020. Jakarta: BPS Kabupaten Administrasi Kepulauan Seribu.

Gaspar, P., Mesías, F. J., Escribano, M., Rodriguez De Ledesma, A., \& Pulido, F. (2007). Economic and management characterization of dehesa farms: Implications for their sustainability. Agroforestry Systems, 71(3), 151-162. https://doi.org/10.1007/s10457-007-9081-6 
Hansmann, R., Mieg, H. A., \& Frischknecht, P. (2012). Principal sustainability components: Empirical analysis of synergies between the three pillars of sustainability. International Journal of Sustainable Development and World Ecology, 19(5), 451-459. https://doi.org/10.1080/13504509.2012.696220

Hurlock, E. B. (1991). Psikologi perkembangan: Suatu pendekatan sepanjang rentang kehidupan (5th ed.). Jakarta: Erlangga.

Kurniawan, F., Adrianto, L., Bengen, D. G., \& Prasetyo, L. B. (2016a). Patterns of Landscape Change on Small Islands: A Case of Gili Matra Islands, Marine Tourism Park, Indonesia. Procedia - Social and Behavioral Sciences, 227(November 2015), 553-559. https://doi.org/10.1016/j.sbspro.2016.06.114

Kurniawan, F., Adrianto, L., Bengen, D. G., \& Prasetyo, L. B. (2016b). Vulnerability assessment of small islands to tourism: The case of the Marine Tourism Park of the Gili Matra Islands, Indonesia. Global Ecology and Conservation, 6, 308-326. https://doi.org/10.1016/j.gecco.2016.04.001

LIPI. (2015). Gugusan Pulau Pari, Pesona yang Perlahan Tergerus. http://www.pksdmo.lipi.go.id/BERITA/Gugusan-Pulau-Pari-Pesona-yang-Perlahan-Tergerus.htm

Nobi, M. N., \& Majumder, M. A. (2019). Coastal and marine tourism in the future. Journal of Ocean and Coastal Economics, 6(2), 1-13. https://doi.org/10.15351/2373-8456.1101

Putranto, A. (2015). Analisis Potensi dan Perkembangan Pariwisata Bahari dan Pengaruhnya Terhadap Kondisi Sosial Ekonomi Masyarakat Pulau Pari, Analisis Potensi dan Perkembangan Pariwisata Bahari: Pengaruhnya Terhadap Kondisi Sosial Ekonomi Masyarakat Pulau Pari, Kepulauan Seribu

[UGM].http://etd.repository.ugm.ac.id/index.php?mod=penelitian_detail\&sub=PenelitianDetail\&ac $\mathrm{t}=$ view\&typ=html\&buku_id=80379\&obyek_id=4,

Radovanović, M., Filipović, S., \& Golušin, V. (2018). Geo-economic approach to energy security measurement - principal component analysis. Renewable and Sustainable Energy Reviews, 82(P2), 1691-1700. https://doi.org/10.1016/j.rser.2017.06.072

Towner, N. (2016). How to manage the perfect wave: Surfing tourism management in the Mentawai Islands, Indonesia. Ocean and Coastal Management, 119, 217-226. https://doi.org/10.1016/j.ocecoaman.2015.10.016

Ziegler, J. A., Silberg, J. N., Araujo, G., Labaja, J., Ponzo, A., Rollins, R., \& Dearden, P. (2019). Applying the precautionary principle when feeding an endangered species for marine tourism. Tourism Management, $\quad$ 72(November 2018 ), 155-158. https://doi.org/10.1016/j.tourman.2018.11.021 